\title{
Influence of weather parameters on progress of rust disease severity in pea (Pisum sativum L.)
}

\author{
Vinod Upadhyay*, K. P. S. Kushwaha and Puja Pandey \\ Department of Plant Pathology, Govind Ballabh Pant University of Agriculture and Technology, Pantnagar-236145 \\ (Uttarakhand), INDIA \\ *Regional Agricultural Research Station, Assam Agricultural University, Gossaigaon- 783360 (Assam), INDIA \\ *Corresponding author. E-mail: vinodupadhyay148@gmail.com
}

Received: June 29, 2016; Revised received: April 21, 2017; Accepted: August 16, 2017

\begin{abstract}
Decision to apply one or more fungicide spray will depend on the risk of rust epidemic in a particular year. Rust epidemic is determined by interaction of three important factors namely, susceptible host, virulent pathogen and the most important i.e. favourable environment for a particular period of time. Therefore, it is necessary to study the correlation between different meteorological parameters and rust severity. Present study revealed that rust disease generally appeared 60 days after sowing and was subsequently increased with a period of time till harvest (4.17 to 64.17 per cent). Disease was observed at a maximum temperature of 16.85 to $24.79{ }^{\circ} \mathrm{C}, 8.09$ to $12.27^{\circ} \mathrm{C}$ minimum temperature, 90.30 to 95.70 percent morning Relative Humidity (RH), 54.80 to 78.40 percent afternoons $\mathrm{RH}, 0.10$ to $5.45 \mathrm{~mm}$ rainfall and wind velocity of 3.93 to $4.23 \mathrm{~km} / \mathrm{hr}$. The correlation between different meteorological parameters and rust severity revealed that per cent disease severity showed highly positive correlation with maximum temperature $(r=0.977)$, minimum temperature $(r=0.704)$, rainfall $(r=0.039)$ and wind velocity $(r=0.093)$ whereas disease severity show negative correlation with morning(r=-0.925) and afternoon RH $(r=-0.926)$. It was observed that the rust severity is highly influenced by the different weather parameters such as temperature, relative humidity, rainfall and wind velocity. This information will help the researchers in formulating the forecasting model for the rust disease in pea and will also supports farmers in decision making regarding time of occurrence of rust epidemic and thereby, allow timely scheduling and need based utilization of fungicides accordingly for the management of pea rust.
\end{abstract}

Keywords: Rainfall, Relative humidity, Rust, Temperature

\section{INTRODUCTION}

A large proportion of Indian population is vegetarian and pulses are the main source of protein for them. The protein content in pulses is about 18-25 per cent. This makes pulse one of the cheapest source of protein for human consumption (Rana and Sharma, 1993). India is the largest producer, consumer and importer of pulses in the world. In India pulses are grown about 24-26 million hectares of area producing 17-19 million tonnes of pulses annually. India accounts for over one third of the total world area and over 20 per cent of total world pulse production. Consequently per capita production and availability of pulses in the country has witnessed sharp decline. Per capita net pulse availability has declined from around 60 grams per day in the 1950s to 40 grams in the 1980s and further to around 35 grams per day in 2000s. However, in the past four years, there has been significant increase in consumption averaging around 50 grams due to higher production, under owing to National Food Security Mission (NFSM), with major emphasis on pulses and their imports, mostly of dry peas from Canada and Australia
(IIPR, 2014).

Major pulses grown in India include chickpea or bengal gram (Cicer arietinum), pigeonpea or red gram (Cajanus cajan), lentil (Lens culinaris), urdbean or black gram (Vigna mungo), mungbean or green gram (Vigna radiata), lablab bean (Lablab purpureus), moth bean (Vigna aconitifolia), horse gram (Dolichos uniflorus), pea (Pisum sativum L.), grass pea or khesari (Lathyrus sativus), cowpea (Vigna unguiculata), and broad bean or faba bean (Vicia faba).

During 2012-13, field pea (P. sativum L.) occupies an area of 0.76 million hectares with a production 0.84 million tonnes and productivity of $1100 \mathrm{~kg} / \mathrm{ha}$ in our country. In Uttarakhand, area, production and productivity of pea during 2012-13 was 61.0 thousand hectares, 51.3 thousand tones and $841 \mathrm{~kg} / \mathrm{ha}$, respectively (NCAER, 2014). Pea is affected by a number of fungal (rust, powdery mildew, downy mildew, root rot, alternaria blight, aschochyta blight, wilt, anthracnose, cercospora leaf spot, damping off, seedling rot etc.), bacterial (bacterial blight and brown spot), nematode (cyst nematode, lesion nematode and root-knot nematode) and viral diseases (cucumber mosaic virus, pea early 
browning virus, pea enation mosaic, pea mosaic, pea seed borne mosaic, pea streak and pea stunt). These diseases, under the right conditions, can significantly decrease both yield and quality. Among these, the rust of pea caused by Uromyces viciae-fabae (Pers.) J. Schrot (syn. Uromyces fabae (Pers.) de Bary) is considered the most important under warm and humid conditions (Chand et al., 2004). It has been reported from different parts of the country including eastern India (Gupta, 1990; Chand et al., 1997), central India (Narsinghani et al., 1980), southern parts of India (Sokhi et al., 1974; Kumar et al., 1994) and from Himalayan region of Uttarakhand and Himachal Pradesh (Chauhan et al., 1991; Sharma, 1998). Rust disease in pea could cause up to $20-100 \%$ losses in yield (Stavely, 1991; Sharma, 1998).

Decision to apply one or more fungicide spray will depend on the risk of rust epidemic in a particular year. Rust epidemic is determined by interaction of three important factors namely, susceptible host, virulent pathogen and most important i.e. favourable environment for a particular period of time. Chauhan and Singh (1994) reported that the severity of infection by $U$. viciae-fabae on pea and the number of rust pustules/ plant increased progressively with increase in the duration of leaf wetness up to $24 \mathrm{~h}$, but, did not increase further significantly. Both were high at $20^{\circ} \mathrm{C}$ under greenhouse and laboratory conditions. It was suggested that the observed relationship between severity of pea rust and duration of leaf wetness at $20^{\circ} \mathrm{C}$ might be useful in predicting disease outbreaks if initial inoculum is present. Likewise, it is very important to know the influence of various weather parameters on progress of rust disease severity in pea. Therefore, present objective has been carried out to study the correlation between different meteorological parameters and rust severity which will ultimately help the farmers in decision making regarding timely scheduling and need based utilization of fungicides for the management of rust disease in pea.

\section{MATERIALS AND METHODS}

Present investigation was carried out in the field during Rabi season 2013-14 and 2014-15 at at N.E. Borlogue Crop Research Centre (NEBCRC), G.B. Pant University of Agriculture and Technology, Pantnagar.

Topographically, Pantnagar falls in the humid and subtropical (Tarai) climate of North West Plain Zone (NWPZ). The zone lies at the foothills of Shivalic range in lower Himalayas. It is situated at $29^{\circ} \mathrm{N}$ latitude and $79.73^{\circ} \mathrm{E}$ longitude, at an altitude of $243.8 \mathrm{~m}$. above the mean sea level (MSL). The average relative humidity is highest (70-80\%) in July-August and December-January, while lowest (35-40\%) in April-May. Average rainfall in this area is about $1400 \mathrm{~mm}$ per annum (GBPUAT meteorological station, Pantnagar). The details of methodology and materials used during the present investigation are presented under the following headings.

Natural occurrence of rust of pea at NEBCRC had been inconsistent. Since environmental conditions especially temperature and humidity play a vital role in occurrence, prevalence and severity of the disease, it was considered to correlate the two years weather data with the disease severity recorded during two successive years, i.e.Rabi 2013-14 and 2014-2015. The weather data was collected from the meteorological observatory located near the experimental plot.

To study the effect of weather parameters on severity of rust, highly susceptible variety HFP-4 was sown with wider spacing of $30 \times 10 \mathrm{~cm}$ in $3.0 \times 2.0 \mathrm{~m}^{2}$ plots. The development of the disease was studied on the basis of symptoms on the leaves. The disease severity was recorded at weekly intervals till the complete drying of the leaves. Then data of individual variety was correlated with various weather parameters viz., temperature (Maximum and minimum), relative humidity (Morning and afternoon) and total rainfall. The weather parameters were correlated with per cent disease severity by calculating the

Karl Pearson's correlation coefficient (r) (Pearson, 1896) as given below:

$$
r=\frac{1}{n-1} \sum \frac{\left(x_{i}-\bar{X}\right)\left(y_{i}-\bar{Y}\right)}{s_{x} s_{y}}
$$

Where, $\mathrm{r}=$ coefficient of correlation, $\mathrm{X}=\left(\mathrm{x}_{\mathrm{i}}-\overline{\mathrm{X}}\right), \mathrm{Y}=$ (yi $-\bar{Y}), S_{x}=$ standard deviation of x series, $S_{y}=$ standard deviation of y series, $\mathrm{n}=$ number of series.

Partial regression equations were calculated for the meteorological factors as independent variable with the prediction equation.

Prediction equation (Pearson, 1930)

$\mathrm{Y}=\mathrm{b}_{0}+\mathrm{b}_{1} \mathrm{X}_{1}+\mathrm{b}_{2} \mathrm{X}_{2} \ldots \ldots \ldots \mathrm{b}_{7} \mathrm{X}_{7} \quad \ldots \ldots \ldots \ldots .2$

Where, $Y=$ Percent disease severity, $b_{0}=$ constant; $b 1$, $\mathrm{b} 2 \ldots . \mathrm{b}_{7}=$ regression coefficients and $\mathrm{X}_{1}, \mathrm{X} 2 \ldots \mathrm{X}_{7}=$ Independent weather variables.

\section{RESULTS AND DISCUSSION}

Year 2013 -2014: The average data (ten days) of disease severity and weather factors for January and February month on temperature (maximum and minimum), relative humidity $(\mathrm{RH})$ (morning and afternoon), rainfall and wind speed has been given in Table 1. First appearance of disease was observed 60 days after sowing and was subsequently increased with a period of time ( 3.33 to 68.33 per cent). Disease was observed at a maximum temperature of 15.52 to $22.83^{\circ} \mathrm{C}, 6.19$ to $10.84^{\circ} \mathrm{C}$ minimum temperature, 90.10 to 97.20 percent morning $\mathrm{RH}, 52.50$ to 77.00 percent afternoon $\mathrm{RH}, 0.14$ to $10.90 \mathrm{~mm}$ rainfall and wind velocity of 3.67 to $6.11 \mathrm{~km} / \mathrm{hr}$.

Correlation among different weather parameters and the disease severity at ten days interval for the year 2013 -2014indicate that the per cent disease severity 
Vinod Upadhyay et al. / J. Appl. \& Nat. Sci. 9 (3): 1724 -1728 (2017)

Table 1. Effect of weather parameters on rust severity in pea (Pisum sativum L.) during 2013-2014.

\begin{tabular}{|c|c|c|c|c|c|c|c|}
\hline \multirow{2}{*}{ Age of crop } & \multirow{2}{*}{$\begin{array}{l}\text { Disease } \\
\text { severity }(\%)\end{array}$} & \multicolumn{2}{|c|}{ Temperature $\left({ }^{\circ} \mathrm{C}\right)$} & \multicolumn{2}{|c|}{ Relative Humidity (RH) } & \multirow{2}{*}{$\begin{array}{l}\text { Rainfall } \\
(\mathrm{mm})\end{array}$} & \multirow{2}{*}{$\begin{array}{l}\text { Wind speed } \\
(\mathrm{km} / \mathrm{hr})\end{array}$} \\
\hline & & Maximum & Minimum & Morning & Afternoon & & \\
\hline 60DAS & 3.33 & 15.52 & 6.19 & 97.20 & 76.90 & 0.20 & 3.67 \\
\hline 70DAS & 13.33 & 17.91 & 8.85 & 94.90 & 74.10 & 10.90 & 4.93 \\
\hline 80DAS & 21.66 & 17.45 & 9.18 & 94.40 & 77.00 & 0.14 & 4.40 \\
\hline 90DAS & 35.00 & 19.83 & 9.72 & 93.00 & 63.70 & 0.20 & 4.39 \\
\hline 100DAS & 48.33 & 20.06 & 6.87 & 94.70 & 61.10 & 9.32 & 6.11 \\
\hline $110 \mathrm{DAS}$ & 68.33 & 22.83 & 10.84 & 90.10 & 52.50 & 2.52 & 4.51 \\
\hline
\end{tabular}

DAS- Days after sowing

Table 2. Correlation coefficients of rust severity with weather parameters in pea (Pisum sativum L.) during 2013-2014.

\begin{tabular}{|c|c|c|c|c|c|c|c|}
\hline & \multicolumn{3}{|c|}{ Temperature $\left({ }^{0} \mathrm{C}\right)$} & \multirow{2}{*}{$\begin{array}{l}\text { Morning RH } \\
(\%)\end{array}$} & \multirow{2}{*}{$\begin{array}{l}\text { Afternoon RH } \\
(\%)\end{array}$} & \multirow{2}{*}{ Rainfall } & \multirow{2}{*}{$\begin{array}{l}\text { Wind veloci- } \\
\text { ty }(\mathrm{km} / \mathrm{hr})\end{array}$} \\
\hline & \multicolumn{2}{|c|}{ Maximum } & nimum & & & & \\
\hline $\begin{array}{l}\text { Percent rust } \\
\text { severity }\end{array}$ & $0.971 * *$ & \multicolumn{2}{|l|}{0.545} & $-0.869 *$ & $-0.959 * *$ & 0.070 & 0.445 \\
\hline \multicolumn{2}{|c|}{$\begin{array}{l}\text { Dependent parameter } \\
\text { Percent rust severity (Y) }\end{array}$} & \multicolumn{3}{|c|}{ Multiple regression equation } & \multicolumn{2}{|c|}{$539.799+17.131 X_{1}-13.773 X_{2}-9.340 X_{3}+2.483 X_{4}-0.826 X_{5}$} & \\
\hline \multicolumn{8}{|c|}{$\begin{array}{l}* * \text { Correlation is significant at } 0.01 \text { level (2-tailed), * Correlation is significant at } 0.05 \text { level (2-tailed), } \mathrm{X}_{1}=\text { Maximum tempera- } \\
\text { ture; } \mathrm{X}_{2}=\text { Minimum temperature; } \mathrm{X}_{3}=\text { Morning } \mathrm{RH} ; \mathrm{X}_{4}=\text { Afternoon } \mathrm{RH}, \mathrm{X}_{5}=\text { Rainfall }\end{array}$} \\
\hline \multirow{2}{*}{ Age of crop } & \multirow{2}{*}{$\begin{array}{l}\text { Disease } \\
\text { severity }(\%)\end{array}$} & \multicolumn{2}{|c|}{ Temperature $\left({ }^{0} \mathrm{C}\right)$} & \multicolumn{2}{|c|}{ Relative Humidity (RH) } & \multirow{2}{*}{$\begin{array}{l}\text { Rainfall } \\
(\mathbf{m m})\end{array}$} & \multirow{2}{*}{$\begin{array}{l}\text { Wind speed } \\
(\mathrm{km} / \mathrm{hr})\end{array}$} \\
\hline & & Maximum & Minimum & Morning & Afternoon & & \\
\hline 60DAS & 5.00 & 18.19 & 10.89 & 94.2 & 79.9 & 2.18 & 5.62 \\
\hline 70DAS & 9.33 & 15.93 & 8.07 & 94.0 & 71.3 & 0.00 & 2.94 \\
\hline 80DAS & 16.00 & 16.82 & 8.12 & 94.3 & 73.0 & 1.10 & 4.86 \\
\hline 90DAS & 25.00 & 21.27 & 8.15 & 89.8 & 56.7 & 0.00 & 4.96 \\
\hline 100DAS & 44.17 & 23.58 & 9.32 & 89.3 & 50.4 & 0.00 & 3.82 \\
\hline 110DAS & 60.00 & 26.76 & 13.70 & 90.5 & 57.2 & 1.09 & 3.95 \\
\hline
\end{tabular}

DAS- Days after sowing

Table 4. Correlation coefficients of rust severity with weather parameters in pea (Pisum sativum L.) during 2014-2015.

\begin{tabular}{|c|c|c|c|c|c|c|c|c|c|}
\hline & \multicolumn{2}{|c|}{$\begin{array}{l}\text { Maximum Tem- } \\
\text { perature }\left({ }^{0} \mathrm{C}\right)\end{array}$} & \multicolumn{2}{|c|}{$\begin{array}{l}\text { Minimum Tem- } \\
\text { perature }\left({ }^{0} \mathrm{C}\right)\end{array}$} & \multicolumn{2}{|c|}{$\begin{array}{l}\text { Morning RH } \\
(\%)\end{array}$} & $\begin{array}{l}\text { Afternoon RH } \\
(\%)\end{array}$ & Rainfall & $\begin{array}{l}\text { Wind veloci- } \\
\text { ty }(\mathrm{km} / \mathrm{hr})\end{array}$ \\
\hline $\begin{array}{l}\text { Percent rust } \\
\text { severity }\end{array}$ & $0.949 * *$ & & 0.618 & & & & $-0.821^{*}$ & -0.233 & -0.310 \\
\hline \multicolumn{4}{|c|}{$\begin{array}{l}\text { Dependent parameter } \\
\text { Percent rust severity (Y) }\end{array}$} & \multicolumn{5}{|c|}{ Multiple regression equation } & \\
\hline \multicolumn{10}{|c|}{$\begin{array}{l}* * \text { Correlation is significant at } 0.01 \text { level (2-tailed), } * \text { Correlation is significant at } 0.05 \text { level }(2 \text {-tailed }), \mathrm{X}_{1}=\text { Maximum tempera- } \\
\text { ture; } \mathrm{X}_{2}=\text { Minimum temperature; } \mathrm{X}_{3}=\text { Morning } \mathrm{RH} ; \mathrm{X}_{4}=\text { Afternoon } \mathrm{RH}, \mathrm{X}_{5}=\text { Rainfall }\end{array}$} \\
\hline \multirow{2}{*}{$\begin{array}{l}\text { Age of } \\
\text { crop }\end{array}$} & \multirow{2}{*}{$\begin{array}{l}\text { Disease } \\
\text { severity }(\%)\end{array}$} & \multicolumn{4}{|c|}{ Temperature $\left({ }^{0} \mathrm{C}\right)$} & \multicolumn{2}{|c|}{ Relative Humidity (RH) } & \multirow{2}{*}{$\begin{array}{l}\text { Rainfall } \\
(\mathrm{mm})\end{array}$} & \multirow{2}{*}{$\begin{array}{l}\text { Wind speed } \\
(\mathrm{km} / \mathrm{hr})\end{array}$} \\
\hline & & \multicolumn{2}{|c|}{ Maximum } & \multicolumn{2}{|c|}{ Minimum } & Morning & Afternoon & & \\
\hline 60DAS & 4.17 & \multicolumn{2}{|c|}{16.85} & \multicolumn{2}{|c|}{8.54} & 95.7 & 78.4 & 1.19 & 4.64 \\
\hline 70DAS & 11.33 & \multicolumn{2}{|c|}{16.92} & 8.46 & & 94.4 & 72.7 & 5.45 & 3.93 \\
\hline 80DAS & 18.83 & \multicolumn{2}{|c|}{17.13} & 8.65 & & 94.3 & 75.0 & 0.62 & 4.63 \\
\hline 90DAS & 30.00 & \multicolumn{2}{|c|}{20.55} & 8.93 & & 91.4 & 60.2 & 0.10 & 4.67 \\
\hline 100DAS & 46.25 & \multicolumn{2}{|c|}{21.82} & 8.09 & & 92.0 & 55.7 & 4.66 & 4.96 \\
\hline 110DAS & 64.17 & \multicolumn{2}{|c|}{24.79} & 12.27 & & 90.3 & 54.8 & 1.80 & 4.23 \\
\hline
\end{tabular}

DAS- Days after sowing

was having a positive correlation with maximum temperature $(\mathrm{r}=0.971)$, minimum temperature $(\mathrm{r}=0.545)$, rainfall $(r=0.070)$ and wind velocity $(r=0.445)$.
Whereas disease severity show negative correlation with morning $(r=-0.869)$ and afternoon relative humidity $(r=-0.959)$ (Table 1 and 2). 
Vinod Upadhyay et al. / J. Appl. \& Nat. Sci. 9 (3): 1724 -1728 (2017)

Table 6. Correlation coefficients of rust severity with weather parameters in pea during 2013-2014 and 2014-2015 (pooled).

\begin{tabular}{|c|c|c|c|c|c|c|}
\hline & \multicolumn{2}{|c|}{ Temperature $\left({ }^{0} \mathrm{C}\right)$} & \multirow{2}{*}{$\begin{array}{l}\text { Morning RH } \\
(\%)\end{array}$} & \multirow{2}{*}{$\begin{array}{l}\text { Afternoon } \\
\text { RH (\%) }\end{array}$} & \multirow{2}{*}{ Rainfall } & \multirow{2}{*}{$\begin{array}{l}\text { Wind velocity } \\
(\mathrm{km} / \mathrm{hr})\end{array}$} \\
\hline & Maximum & Minimum & & & & \\
\hline $\begin{array}{l}\text { Percent rust } \\
\text { severity }\end{array}$ & $0.977 * *$ & 0.704 & $-0.925 * *$ & $-0.926 * *$ & 0.039 & 0.093 \\
\hline \multicolumn{2}{|c|}{ Dependent parameter } & \multicolumn{5}{|c|}{ Multiple regression equation } \\
\hline \multicolumn{2}{|c|}{ Percent Disease Severity (Y) } & \multicolumn{5}{|c|}{$3650.867+51.334 \mathrm{X}_{1}-45.112 \mathrm{X}_{2}-61.164 \mathrm{X}_{3}+21.867 \mathrm{X}_{4}+10.584 \mathrm{X}_{5}$} \\
\hline
\end{tabular}

** Correlation is significant at 0.01 level (2-tailed), $\mathrm{X}_{1}=$ Maximum temperature; $\mathrm{X}_{2}=$ Minimum temperature; $\mathrm{X}_{3}=\mathrm{Morning}_{\mathrm{RH}}$; $\mathrm{X}_{4}=$ Afternoon $\mathrm{RH}, \mathrm{X}_{5}=$ Rainfall

The multiple linear regression equation after step down elimination for disease severity was, $\mathrm{Y}=$ $539.799+17.131 X_{1}-13.773 X_{2}-9.340 X_{3}+2.483 X_{4}-$ $0.826 \mathrm{X}_{5}$ indicating an unit increase in maximum temperature and relative humidity (afternoon), enhance the disease severity by 17.131 and 2.483 units. Whereas every unit increase in minimum temperature, relative humidity (morning) and rainfall will decrease the severity of disease by $13.773,9.340$ and 0.826 units (Table 2.).

Year 2014-2015: During 2014-2015, first appearance of disease was observed 60 days after sowing and was subsequently increased with a period of time (5.00 to 60.00 per cent). Disease was observed at a maximum temperature of 15.93 to $26.76^{\circ} \mathrm{C}, 8.07$ to $13.70^{\circ} \mathrm{C}$ minimum temperature, 89.3 to 94.30 morning $\mathrm{RH}, 50.40$ to 79.90 afternoon $\mathrm{RH}, 0.00$ to 2.18 rainfall and wind velocity of 2.94 to 5.62 (Table 3 ).

Correlation among different weather parameters and the disease severity at ten days interval for the year 2014 -2015indicate that the per cent disease severity was having a positive correlation with maximum temperature (0.949) and minimum temperature (0.618). Whereas disease severity show negative correlation with morning (-0.782), afternoon relative humidity ($0.821)$, rainfall $(-0.233)$ and wind velocity $(-0.310)$ (Tables 3 and 4.).

The multiple linear regression equation after step down elimination for disease severity was, $\mathrm{Y}=-1177.812$ $+8.947 \mathrm{X}_{1}-3.553 \mathrm{X}_{2}+12.490 \mathrm{X}_{3}-1.413 \mathrm{X}_{4}-2.236 \mathrm{X}_{5}$ indicating an unit increase in maximum temperature and morning relative humidity enhance the disease severity by 8.947 and 12.490 units. Whereas every unit increase in minimum temperature, relative humidity (afternoon) and rainfall will decrease the severity of disease by $3.553,1.413$ and 2.236 units (Table 4.).

Pooled data of 2013-2014 and 2014-2015: The pooled data (Table 5) of the year 2013-2014 and 20142015 revealed that disease initiation was first observed 60 days after sowing and was subsequently increased with a period of time (4.17 to 64.17 per cent). Disease was observed at a maximum temperature of 16.85 to $24.79^{\circ} \mathrm{C}, 8.09$ to $12.27^{\circ} \mathrm{C}$ minimum temperature, 90.30 to 95.70 morning $\mathrm{RH}, 54.80$ to 78.40 afternoons $\mathrm{RH}$, 0.10 to 5.45 rainfall and wind velocity of 3.93 to 4.23 . Correlation among different weather parameters and the disease severity at ten days interval for both the year 2013-2014 and 2014-2015 indicate that the per cent disease severity was having a highly positive correlation with maximum temperature $(0.977)$, minimum temperature $(0.704)$, rainfall $(0.039)$ and wind velocity (0.093) whereas disease severity show negative correlation with morning $(-0.925)$ and afternoon relative humidity (-0.926) (Table 5 and 6.).

The multiple linear regression equation after step down elimination for disease severity was, $\mathrm{Y}=3650.867$ $+51.334 \mathrm{X}_{1}-45.112 \mathrm{X}_{2}-61.164 \mathrm{X}_{3}+21.867 \mathrm{X}_{4}+10.584 \mathrm{X}_{5}$ indicating an unit increase in maximum temperature, relative humidity (afternoon) and rainfall enhance the disease severity by $51.334,21.867$ and 10.584 units. Whereas every unit increase in minimum temperature and relative humidity (morning) will decrease the incidence of disease by 45.112 and 61.164 units (Table 6.).

The rust severity is highly influenced by the different weather parameters such as temperature, relative humidity, rainfall and wind velocity. The results of the present investigation revealed that the rust severity has positive relationship with temperature, rainfall and wind velocity whereas it shows negative correlation with relative humidity. Similar results were found by Bal and Kumar (2012) who mentioned highly significant positive correlation between the disease severity and the maximum and minimum temperatures. Singh et al. (2012) also observed significant and positive correlation between rust severity and temperature. However, disease severity has a strong negative correlation with relative humidity. Many more researchers have observed the similar relationship between different weather parameters and rust severity. Stavely (1991) stated that moist weather with a temperature of $15-24^{0} \mathrm{C}$ increased the severity of pea rust. Kushwaha et al. (2006) reported the germination of aeciospores of pea rust favoured by a temperature in the range of $10-25^{\circ} \mathrm{C}$. Joshi and Tripathi (2012) observed that a temperature of $20^{\circ} \mathrm{C}$ is optimum for the germination of aeciospores, uredospores and teliospores of rust disease of lentil.

This justifies the importance of weather factors in rust disease development. Long term research on role of weather factors need to be carried out for the development of appropriate forecasting model.

\section{Conclusion}

The correlation between different meteorological parameters and rust severity revealed that per cent dis- 
ease severity showed highly positive correlation with maximum temperature, minimum temperature, rainfall and wind velocity whereas disease severity show negative correlation with morning and afternoon relative humidity. This information will help the researchers in formulating the forecasting model for the rust disease in pea. The study will also help farmers in decision making regarding time of occurrence of rust epidemic and thereby, allow timely scheduling and need based utilization of fungicides accordingly for the management of pea rust.

\section{REFERENCES}

Bal, R.S. and Kumar, A. (2012). Influence of weather parameters on pea rust development and its effect on yield. $P l$. Dis. Res., 27 (2): 162-164.

Chand, R., Srivastava, C.P., Kushwaha, C. (2004). Screening technique for pea (Pisum sativum L.) genotypes against rust disease (Uromyces fabae Pers. de Bary). Indian J. Agric. Sci., 74: 166-167.

Chand, R.; Srivastava, C.P.; Singh, R.M. and Singh R.B. (1997). Pea specific strains in Uromyces fabae. Indian J. Pul. Res., 10:127-128.

Chauhan, R.S. and Singh, B.M. (1994). Effect of different durations of leaf wetness on pea rust development. $P l$. Dis. Res., 9(2): 200-201.

Chauhan, R.S., Sugha, S.K. and Singh, B.M. (1991). A note on the prevalence and distribution of pea rust in Himachal Pradesh. Him. J. Agric. Res., 17:105-107.

Gupta, R.P. (1990). Evaluation of pea germplasm for their reaction to powdery mildew and rust. Indian J. Pul. Res., 3:186-188.

Indian Institute of Pulses Research (IIPR), (2014). E- Pulses data book.
Joshi, A. and Tripathi, H.S. (2012). Studies on epidemiology of lentil rust (Uromyces viciae fabae).Indian Phytopath., 65 (1): 67-70.

Kumar, T.B.A., Rangaswamy, K.T. and Ravi, K. (1994). Assessment of tall field pea genotypes for slow rusting resistance. Legume Res., 17:79-82.

Kushwaha, C., Chand, R. and Srivastava, C.P. (2006). Role of aeciospores in outbreaks of pea (Pisum sativum) rust (Uromyces fabae). Europian J. Pl. Path. 115: 323-330.

Narsinghani, V.G., Singh, S.P. and Pal B.S. (1980). Note on rust resistance pea varieties. Indian J. Agric. Sci., 50:453.

National Council of Applied Economic Research (NCAER) (2014). India's Pulses scenario.

Pearson, K. (1896). Mathematical Contributions to the Theory of Evolution. III. Regression, Heredity and Panmixia. Philosophical Transactions of the Royal Society of London, 187: 253-318.

Pearson, K. (1930). The Life, Letters and Labors of Francis Galton. Cambridge University Press.

Rana, K.S. and Sharma, S.K. (1993). Effect of rabi legumes on nitrogen economy and productivity of direct seeded upland rice. Crop Research, 6:165-167.

Sharma, A.K. (1998). Epidemiology and management of rust disease of French bean. Veg. Sci., 25:85-88.

Singh, D., Tripathi, H.S., Singh, A.K. and Gupta, A.K. (2012). Effects of sowing dates and weather parameters on severity of field pea. J. Pl. Dis. Sci., 7: 147-149.

Sokhi, H.S., Sokhi, S.S. and Rawal, R.D. (1974). Vertical reaction of pea to powdery mildew (Erysiphe polygoni) and rust (Uromyces vicia fabae). Mysore J. Agril. Sci., 8:529-532.

Stavely, J. R. (1991). Compendium of Bean Diseases. APS Press, St Paul, MN. pp 24-25. 